\title{
PENGARUH MANAJEMEN MODAL KERJA TERHADAP PROFITABILITAS PADA PERUSAHAAN MANUFAKTUR
}

\author{
Yunia Panjaitan \\ Bandi Wijaya \\ Unika Atma Jaya \\ e-mail : yunia.panjaitan@atmajaya.ac.id
}

\begin{abstract}
Working capital is needed for day to dayoperations of a firm. The primary purpose of this research was to examine the effect ofworking capital managementincluding average receivable period, average inventory period, average payment period, and cash conversion cycle on operating income ratio of firms. Debt ratio, size, financial assets to total asset ratio, and sales growth have been used as control variables. In this research, samples have used 119 manufacture firms listed on Indonesia Stock Exchange for period 2008-2012. The analytical method used is the analysis descriptif and analysis of panel data regression with random effect model. The results show that there is a negative significant effect between average receivable period, average inventory period, and cash conversion cycle on operating income ratio. It means, managers can increase the profitability of the firm by shortening the cash conversion cycle, average receivable period, and average inventory period to a possible minimum level.
\end{abstract}

Keywords: working capital, cash conversion cycle, profitability.

\section{PENDAHULUAN}

Seiring berkembangnya jaman membuat persaingan antar perusahaan menjadi semakin ketat. Perusahaan dituntut untuk menghasilkan laba agar dapat bertahan dan berkembang menghadapi persaingan. Kinerja keuangan menjadi salah satu aspek yang diperhatikan untuk dapat menghasilkan laba bagi perusahaan. Salah satu komponen kinerja keuangan adalah modal kerja. Modal kerja memiliki peran penting dalam operasi sehari-hari perusahaan karena mempengaruhi likuiditas dan profitabilitas perusahaan. Manajer keuangan sebagai pembuat kebijakan seringkali menghabiskan sebagian waktu kerja sehari-hari untuk mengatur penggunaan modal kerja atau yang sering disebut manajemen modal kerja.

Martin et al. (2001) mengatakan manajemen modal kerja meliputi pengelolaan investasi dalam aktiva lancar dan penggunaan kewajiban lancar. Aktiva lancar yang dimaksud meliputi kas, piutang, dan persediaan. Aktiva lancar merupakan aset yang paling likuid karena dapat dengan cepat dikonversikan menjadi uang tunai. Kewajiban lancar meliputi utang usaha, wesel bayar, pinjaman bank jangka pendek, utang pajak, dan utang lainnya yang jatuh tempo kurang dari satu tahun. Pengelolaan modal kerja melibatkan mengenai komposisi dan berapa jumlah harta lancar yang harus dimiliki perusahaan serta bagaimana perusahaan membiayai aktiva tersebut. 
Pada perusahaan manufaktur, modal kerja sangat penting karena sebagian dari total aktiva perusahaan merupakan aktiva lancar yang memerlukan perhatian seksama dari manajer keuangan (Weston dan Copeland, 1989). Modal kerja pada perusahaan manufaktur tertanam pada akun-akun seperti piutang dagang (account receivables), persediaan (inventories), dan pembayaran atas hutang jangka pendek (account payables). Keputusan mengenai pengelolaan modal kerja langsung mempengaruhi tingkat probabilitas perusahaan.

Peusahaan yang memiliki modal kerja yang optimal dapat memaksimalkan nilai perusahaan. Disisi lain, inventori dalam jumlah besar dan pemberian kredit kepada pelanggan atas penjualan dapat meningkatkan penjualan perusahaan. Inventori dalam jumlah besar yang dimiliki perusahaan dapat mengurangi risiko kehabisan stok. Kredit penjualan merupakan salah satu cara untuk menstimulasi penjualan karena pelanggan dapat mengakses kualitas dari produk sebelum melakukan pembayaran. kelemahan pemberian kredit atas penjualan dan memiliki persediaan dalam jumlah besar membuat uang kas menjadi tertanam dalam modal kerja (Deloof, 2003). Komponen lain dalam modal kerja yaitu hutang. Menunda pelunasan hutang kepada pemasok membuat perusahaan dapat mengakses kualitas pembelian bahan baku terlebih dahulu, dan dapat meminimalkan biaya serta membuat pembayaran menjadi fleksibel. Di sisi lain, keterlambatan pelunasan hutang dapat meningkatkan biaya jika pemasok menawarkan diskon untuk pembayaran lebih awal (Deloof, 2003). Oleh karena, modal kerja beserta komponennya perlu dikelola secara efisien karena dapat mempengaruhi tingkat profitabilitas perusahaan.

Menurut Deloof (2003) ukuran efisiensi modal kerja adalah Cash Conversion Cycle (CCC). CCC adalah beda waktu antara pembayaran atas pembeliaan bahan baku dan pengumpulan penjualan atas barang jadi.
Semakin besar $\mathrm{CCC}$, tingkat keuntungan yang diperoleh dapat meningkat karena penjualan yang meningkat pula. Namun semakin besar CCC juga berpotensi menurunkan keuntungan apabila biaya investasi modal kerja meningkat lebih cepat dibandingkan dengan keuntungan dari memiliki persediaan yang banyak atau memberikan kredit pada pelanggan. Dengan kata lain dapat dikatakan bahwa manajemen modal kerja dan komponennya memiliki pengaruh dan hubungan dua arah terhadap tingkat profitabilitas perusahaan.

\section{REVIEW LITERATUR DAN HIPOTESIS}

Banyak peneliti yang telah melakukan penelitian mengenai manajemen modal kerja dari sudut pandang dan lingkungan yang berbeda. Beberapa dari penelitian tersebut menarik dan berguna untuk penelitian ini:

Penelitian dari Deloof (2003) yang membahas apakah manajemen modal kerja berpengaruh terhadap profitabilitas perusahaan non keuangan di Belgia.Dengan menggunakan analisis regresi dan korelasi Deloof menyatakan bahwa number of days account recceivable, number of days inventory, number of days account payable, debt ratio berpengaruh negatif dan signifikan terhadap gross operating income. Berdasarkan temuan tersebut Deloof menyatakan manajer dapat menciptakan nilai bagi pemegang saham dengan memperpendek number of days account receivable dan number of days inventory sampai batas minumim dan rasional. Deloof juga menyatakan bahwa Cash Conversion Cycle tidak mempunyai hubungan yang signifikan terhadap gross operating income.

Raheman and Nasr (2007) Dalam penelitian yang menggunakansampel dari 94 perusahaan Pakistan yang terdaftar di Bursa Efek Karachi selama 6tahun dari 1999 - 2004. Hasil penelitian menunjukkan bahwa ada yangnegatif antara variabel pengelolaan modal kerja dan 
profitabilitas perusahaan.Ini berarti bahwa sebagai siklus konversi kas (cash conversion cycle) meningkat maka akan mengakibatkan penurunan profitabilitas perusahaan, dan manajer dapatmenciptakan nilai positif bagi pemegang saham dengan mengurangi siklus konversi kas (cash conversion cycle) ke tingkat minimum. Penelitian ini menemukan bahwa ada hubungannegatif signifikan antara likuiditas dan profitabilitas.Penelitian ini juga menemukanbahwa ada hubungan positif antara ukuran (size) perusahaan dan profitabilitas. Adajuga hubungan negatif yang signifikan antara hutang (debt ratio) yang digunakan olehperusahaan dan profitabilitas.Persamaan dalam penelitian ini adalah sama-samameneliti pengaruh manajamen modal kerja efisien terhadap profitabilitas.Perbedaanya dalam penelitian ini adalah obyek penelitian danwaktu penelitiannya.

Napompech (2012) pernah meneliti mengenai pengaruh manajemen modal kerja terhadap profitabilitas pada 225 perusahaan yang terdaftar di Bursa Efek Thailand periode 20072009. Hasil dari penelitian tersebut menjelaskan bahwa ada hubungan negatif antaragross operating profits dan inventory conversion period dan receivables collection period. Perusahaan dapat meningkatkan profitabilitas dengan dua cara yaitu: meminimalkan inventory conversion period dengan produksi dan penjualan barang lebih cepat, dan mengurangi receivables collection period dengan mempercepat pengumpulan piutang. Penelitian ini juga menemukan hubungan yang terbalik antara profitabilitas dan payable defferal periode.

Gill et al. (2010) menelitian mengenai hubungan antara manajemen modal kerja dan profitabilitas pada 88 perusahaan berukuran kecil yang terdaftar pada Bursa Efek New York periode 2005-2007.Hasil dari penelitian tersebut tidak menemukan hubungan yang signifikan antara periode perputaran utang rata-rata (average days of payable) dengan profitabilitas perusahaan.
Penelitian ini juga tidak menemukan hubungan yang signifikan antara perputaran persediaan rata-rata (average number of days inventory) dengan profitabilitas dan tidak menemukan hubungan antara ukuran perusahaan dengan profitabilitas. Penelitian ini menemukan adanya hubungan yang positif antara siklus konversi kas (cash conversion cycle) dengan profitabilitas dan menemukan bahwa hubungan negatif antara perputaran piutang dagang (average number of days receivable) dengan profitabilitas (yang diukur dengan gross operating income). Dengan demikian manajer dapat meningkatkan profit atau bahkan nilai bagi pemilik perusahaan dengan mengurangi perputaran piutang dagangnya.

\section{METODE PENELITIAN}

Data yang digunakan dalam penelitian ini adalah tahun 2008-2012, dimana data tersebut terdiri dari data kualitatif laporan keuangan. Data diambil dari laporan keuangan perusahaan manufakturyangterdaftardiBursaEfekIndonesia. Data yang digunakan berupa angka akun-akun aktiva seperti piutang, persediaan, dan total aktiva, akun-akun passiva seperti hutang lancar dan total kewajiban perusahaan, kemudian angka penjualan, beban pokok penjualan, depresiasi yang dialokasikan ke dalam beban pokok penjualan, dan laba operasi perusahaan. Sampel yang digunakan berdasarkan laporan keuangan dari 119 perusahaan manufaktur yang terdaftar di Bursa Efek Indonesia.Hanya perusahaan yang memiliki data lengkap dan terdaftar di bursa sejak 2008 yang menjadi sampel dalam penelitian ini.

Adapun Variabel dependen yang digunakan untuk mengukur profitabilitas dalam penelitian ini adalah Gross Operating Income Ratio (GOIR) dan Net Operating Income Ratio (NOIR). GOIR didapat dari hasil penjualan dikurangi beban pokok penjualan ditambah dengan beban depresiasi yang dialokasikan ke beban pokok penjualan dan dibagi dengan total 
aset dikurangi aset finansialnya. NOIR didapat dari hasil penjualan dikurangi beban pokok penjualan termasuk dengan beban depresiasi dibagi total aset dikurangi aset finansialnya. Alasan peneliti menggunakan variabel ini daripada menggunakan EBIT atau laba setelah atau sebelum pajak adalah karena peneliti ingin menghubungkan "sukses" atau "gagal" operasi perusahaan dengan menggunakan rasio operasi di bawah ini dan menghubungkannya dengan rasio operasi yang lainnya seperti siklus konversi kas.

Average Receivable Period (ARP) digunakan sebagai variabel independen atas kebijakan piutang.ARP didapat dari rata-rata piutang dagang dikali 365 hari dan dibagi total penjualan.

Average Inventory Period (AIP) digunakan sebagai variabel independen atas kebijakan persediaan. Average Payment Period (APP) digunakan sebagai variabel independen atas kebijakan utang dagang. Cash Conversion Cycle (CCC) digunakan sebagai variabel independen untuk mengukur efisiensi dari manajemen modal kerja. Size (natural logaritma dari total penjualan (LOS)), Sales Growth (SG) digunakan untuk mengukur tingkat pertumbuhan penjualan perusahaan. Debt Ratio (DR) digunakan untuk mengukur kebijakan struktur modal dan likuidasi perusahaan. Fixed Financial Asset Ratio (FATA) digunakan sebagai variabel kontrol. Fixed Financial Asset Ratio adalah Rasio atas penyertaan jangka panjang maupun jangka pendek (investasi) di perusahaan lain, yang berkontribusi terhadap aktivitas dari perusahaan pemegang saham tersebut dengan membangun hubungan yang erat dan spesifik serta pinjaman yang dijaminkan untuk tujuan yang sama.

\section{Hipotesis}

Terdapat beberapa hipotesis yang dikembangkan dalam penelitian ini, diantaranya:
$\mathrm{H}_{1}$ : Terdapat pengaruh antaramanajemen modal kerja dengan profitabilitas pada perusahaan manufaktur yang terdaftar di BEI periode 2008-2012.

$\mathrm{H}_{2}$ : Terdapat pengaruh antarapenggunaan utang dengan profitabilitas pada perusahaan manufaktur yang terdaftar di BEI periode 2008-2012.

$\mathrm{H}_{3}$ : Terdapat pengaruh antara ukuran perusahaan (total penjualan) dengan profitabilitas pada perusahaan manufaktur yang terdaftar di BEI periode 2008-2012.

$\mathrm{H}_{4}$ : Terdapat pengaruh antara pertumbuhan penjualan dengan profitabilitas pada perusahaan manufaktur yang terdaftar di BEI periode 2008-2012.

\section{Model Penelitian}

Penelitian ini menggunakan regresi dengan data panel. Peneliti menggunakan model efek acak (Random Effect Model) dalam penelitian ini. Pada model Random Effect, intercept $\alpha$ merepresentasikan nilai rata - rata dari seluruh cross-sectional intercept dan perbedaan antar individu tersebut diakomodasi lewat error terms masing-masing individu. Perasamaan dasar random effect model (REM) dapat ditulis sebagai berikut:

$\mathrm{Y}_{\mathrm{it}}=\alpha_{1}+\beta_{1} \mathrm{X}_{1 \mathrm{it}}+\ldots .+\beta_{1} \mathrm{X}_{\mathrm{nit}}+\mathrm{e}_{\mathrm{it}}+\mathrm{u}_{\mathrm{it}} \ldots \ldots .$. (3.1)

Alih-alih memperlakukan ai sebagai fixed, model random effect mengasumsikan bahwa ai sebagai variabel acak dengan nilai rata-rata $\alpha$. Dan nilai intercept untuk masing-masing unit cross section dapat dituliskan sebagai berikut:

$\alpha \mathrm{i}+\mathrm{ui} \quad \mathrm{N}=1,2, \ldots . . \mathrm{N} \ldots \ldots \ldots \ldots \ldots \ldots \ldots \ldots \ldots(3.2)$

Model utama diatas dispesifikasi sesuai dengan variabel-variabel yang digunakan dalam penelitian ini menjadi sebagai berikut:

$$
\begin{aligned}
\operatorname{GOIR}_{i t}= & \beta_{0}+\beta_{1}\left(\mathrm{ARP}_{\mathrm{it}}\right)+\beta_{2}\left(\mathrm{AIP}_{\mathrm{it}}\right)+\beta_{3}\left(\mathrm{APP}_{\mathrm{it}}\right) \\
& +\beta_{4}\left(\mathrm{CCC}_{\mathrm{it}}\right)+\beta_{5}\left(\mathrm{DR}_{\mathrm{it}}\right)+\beta_{3}\left(\mathrm{FATA}_{\mathrm{it}}\right)+ \\
& \beta_{4}\left(\mathrm{LOS}_{\mathrm{it}}\right)+\beta_{5}\left(\mathrm{SG}_{\mathrm{it}}\right)+\varepsilon \ldots \ldots \ldots(3.3)
\end{aligned}
$$




$$
\begin{aligned}
\mathrm{NOIR}_{i t}= & \beta_{0}+\beta_{1}\left(\mathrm{ARP}_{\mathrm{it}}\right)+\beta_{2}\left(\mathrm{AIP}_{\mathrm{it}}\right)+\beta_{3}\left(\mathrm{APP}_{\mathrm{it}}\right) \\
& +\beta_{4}\left(\mathrm{CCC}_{\mathrm{it}}\right)+\beta_{5}\left(\mathrm{DR}_{\mathrm{it}}\right)+\beta_{3}\left(\mathrm{FATA}_{\mathrm{it}}\right)+ \\
& \beta_{4}\left(\mathrm{LOS}_{\mathrm{it}}\right)+\beta_{5}\left(\mathrm{SG}_{\mathrm{it}}\right)+\varepsilon \ldots \ldots \ldots(3.4)
\end{aligned}
$$

Dimana:

$\begin{array}{ll}\text { GOIR } & \text { : Gross Operating Income Ratio } \\ \text { NOIR } & : \text { Net Operating Income Ratio } \\ \text { ARP } & : \text { Average Receivable Period } \\ \text { AIP } & : \text { Average Inventory Period } \\ \text { APP } & : \text { Average Payment Period } \\ \text { CCC } & : \text { Cash Convertion Cycle } \\ \text { DR } & : \text { Debt Ratio } \\ \text { FATA } & : \text { Fixed Financial Asset Ratio } \\ \text { LOS } & : \text { Natural Logarithm of Sales } \\ \text { SG } & : \text { Sales Growth } \\ \varepsilon & : \text { Error Term }\end{array}$

Dalam penelitian ini digunakan dua tipe analisis data yaitu: deskriptif dan regresi. Dalam penelitian ini analisis deskriptif memberikan gambaran mengenai fenomena mengenai manajemen modal kerja dan profitabilitas perusahaan serta memberikan informasi mengenai variabelvariabel terkait dalam penelitian. Analisis deskriptif menunjukkan data mengenai nilai rata-rata, standar deviasi, nilai minimum dan maksimum dari masing-masing variabel. Analisis deskriptif dalam penelitian ini didapat dengan bantuansoftware SPSS 17.

Analisis regresi yang digunakan dalam penelitian ini adalah analisis regresi data panel dengan model random effect. Analisis ini bertujuan untuk mengetahui pengaruh manajemen modal kerja serta variabel terkait lainnya dengan profitabilitas perusahaan. Untuk menguji pengaruh variabel independen terhadap independen secara bersama-sama, peneliti menggunakan uji simultan (uji F) dan untuk melihat pengaruh dari masing-masing variabel independen terhadap variabel dependen menggunakan uji parsial (uji t).Analisi regresi dalam penelitian ini didapat dengan bantuan aplikasi E-views 8.0.

\section{HASIL PENELITIAN DAN PEMBAHASAN}

\section{Analisis Deskriptif}

Analisis desktiptif bertujuan untuk meringkas dan menggambarkan informasi tanpa merusak gambaran umumnya. Analisis deskriptif menunjukkan rata-rata (mean), standar deviasi serta nilai minimum dan maksimum dari setiap variabel yang terlibat dalam penelitian ini, sehingga dapat diketahui gambaran nilai minimum dan maksimum yang didapat dari setiap variabel. Untuk mendapatkan analisis deskriptif digunakan software SPSS 17 dengan output sebagai berikut:

\section{Tabel 1}

\begin{tabular}{|c|c|c|c|c|c|}
\hline Variable & $N$ & Minimum & Maximum & Mean & $\begin{array}{c}\text { Std. } \\
\text { Deviation }\end{array}$ \\
\hline $\begin{array}{l}\text { GOIR } \\
\text { NOIR } \\
\text { ARP } \\
\text { AIP } \\
\text { APP } \\
\text { CCC } \\
\text { SG } \\
\text { DR } \\
\text { LOS } \\
\text { FATA }\end{array}$ & $\begin{array}{l}595 \\
595 \\
595 \\
595 \\
595 \\
595 \\
595 \\
595 \\
595\end{array}$ & $\begin{array}{c}-.4233 \\
-.45582 \\
.0065 \\
.0000 \\
-831.9853 \\
-.9149 \\
+0395 \\
.3796 \\
.0000\end{array}$ & $\begin{array}{c}1.2261 \\
1.2080 \\
490.6557 \\
2089.6995 \\
1498.8875 \\
808.6858 \\
53.3948 \\
6.0813 \\
19.0522 \\
.5014\end{array}$ & $\begin{array}{r}.261117 \\
.228326 \\
58.453605 \\
46.450986 \\
41.909824 \\
.2314760 \\
.610810 \\
13947953 \\
.025355\end{array}$ & $\begin{array}{r}.2185444 \\
4830474 \\
109485395 \\
109.8143856 \\
97.093606 \\
2.2683451 \\
5388187 \\
1.7519962 \\
.0665886\end{array}$ \\
\hline $\begin{array}{l}\text { Valid N } \\
\text { (listwise) }\end{array}$ & 595 & & & & \\
\hline
\end{tabular}

Analisis deskriptif 119 perusahaan manufaktur periode 2008-2012

Sumber: Olahan SPSS 17.0

Berdasarkan tabel 1 mengenai analisis deskriptif 119 perusahaan manufaktur periode 2008-2012 diperoleh gambaran sebagai berikut:

1. Nilai mean dari GOIR (Gross Operating Income Ratio) adalah 26,11\% dengan standar deviasi 21,85\%, hal ini dapat diartikan bahwa nilai GOIR dapat menyimpang ke kedua sisi sejauh $21,85 \%$. Nilai maksimum dari GOIR adalah $122 \%$ dan nilai minimunnya $-42 \%$ dari total aset dikurangi aset finansial dalam setahun.

2. Nilai mean dari NOIR adalah $22,83 \%$ dan dapat menyimpang ke kedua sisi sebesar $22,30 \%$. Nilai maksimum dan minimumnya masing-masing adalah $120 \%$ dan $-46 \%$.

3. Rata-rata waktu yang dibutuhkan perusahaan manufaktur untuk menerima pembayaran atas piutang mereka adalah 58,45 hari dengan standar deviasi 48,04 hari. Waktu maksimum 
dan minimum yang diperlukan perusahaan untuk menerima pembayaran adalah 490,65 hari dan 0.55 hari.

4. Perusahaan manufaktur membutuhkan waktu rata-rata 80,45 hari untuk mengkonversi persediaan sampai dengan menjualnya. Standar deviasinya sebesar 109,41 hari dengan waktu maksimum 2089,69 hari.

5. Rata-rata perusahaan menunda selama 46,90 hari sebelum membayar pembelian yang mereka lakukan dengan standar deviasi 109,88 hari. Waktu minimum yang dibutuhkan perusahaan untuk melakukan pembayaran atas hutangnya adalah 0,00 hari, nilai ini tidaklah biasa. Sedangkan waktu maksimum yang dibutuhkan untuk pembayaran hutang 1498,88 hari dimana nilai ini sangatlah besar.

6. Cash Conversion Cycle (CCC) yang digunakan sebagai variabel independen dan suatu ukuran untuk mengukur efisiensi manajemen modal kerja memiliki rata-rata 91,99 hari dengan standar deviasi sebesar 97,09 hari.

Seperti yang telah disebutkan dalam penjelasan variabel, untuk mengetahui pengaruh pertumbuhan perusahaan dengan profitabilitas digunakan Sales Growth dari penjualan sebagai variabel kontrol. Nilai rata-rata dari SG ini adalah 23,14\% sepanjang tahun 2008-2012 dan dengan standar deviasi 226,83\%. Pertumbuhan penjualan tertinggi mencapai $5.339,48 \%$ dan pertumbuhan terendah mencapai $-91,49 \%$. Variabel lainnya adalah Debt Ratio yang digunakan untuk mengetahui hubungan tingkat hutang dengan profitabilitas perusahaan. Hasil analisis deskriptif perusahaan menunjukkan rata-rata DR pada perusahaan manufaktur yang terdaftar di BEI sebesar $61,08 \%$ dengan standar deviasi 53,88\%. Nilai maksimum DR pada perusahaan-perusahaan tersebut adalah $608,13 \%$ dari total asetnya, nilai ini tidak wajar, namun memungkinkan terjadi dan dapat disebabkan oleh disefisiensi ekuitas atau nilai ekuitas negatif. Nilai minimumnya 3,95\%.

Variabel berikutnya yang digunakan untuk mengetahui pengaruh ukuran perusahaan dengan profitabilitas adalah natural logarithm dari penjualan. Nilai rata-rata dari $\operatorname{LOS} 13,94$ dengan standar deviasi 1,75. Nilai maksimum dan minimum masing-masing dari LOS adalah 19,05 dan 7,37. Kemudian, variabel FATA memiliki nilai rata-rata $2,53 \%$ dari nilai aset dan dengan standar deviasi 0,066\%. Nilai maksimum FATA yang dimiliki oleh perusahaan-perusahaan tersebut adalah 50,14\% dan nilai minimumnya adalah $0 \%$, hal ini disebabkan karena lebih dari $60 \%$ perusahaan manufaktur yang terdaftar di Bursa Efek Indonesia tidak memiliki aset finansial dan sisanya hanya memiliki aset finansial dengan jumlah yang sangat kecil.

\section{Analisis Regresi}

Untuk mengidentifikasi pengaruh manajemen modal kerja terhadap profitabilitas perusahaan, peneliti menggunakan analisis regresi dengan metode random effect.Penggunaan data ekonomi dalam penelitian seringkali melanggar asumsi-asumsi klasik seperti multikolinearitas, heteroskedastisitas, dan autokorelasi.Menurut Gujarati (2003), metode random effect adalah salah satu metode yang bersifat Generalized Least Square (GLS). Regresi data panel dengan metoderandom effect mengasumsikan bahwa seluruh model telah terbebas dari masalah heteroskedastisitas dan autokorelasi. Penelitian menggunakan data panel lebih berguna dalam mempelajari mengenai dinamika perubahan dan lebih baik mengidentifikasi dan mengukur pengaruh yang tidak dapat dideteksi oleh data yang hanya bersifat cross-section ataupun time-series. Penggunaan data panel juga dapat mengukur variabel lebih akurat pada tingkat mikro dan dapat menghilangkan bias dari kelebihan perusahaan atau individu. 
Regresi Model: Random Effect - Variabel Dependen Gross Operating Income Ratio

Untuk mengetahui faktor-faktor penentu gross operating income ratio dilakukan regresi terhadap 595 observasi. Hasil regresi terlampir pada lampiran. Untuk menguji hipotesis dan menganalisa pengaruh setiap variabel independen terhadap variabel dependen.

Regresi pertama menggunakan variabel average receivable period (ARP) sebagai variabel independen utama dan debt ratio, fixed financial asset ratio, natural logarithm of sales dan sales growth sebagai variabel kontrol. Model regresinya sebagai berikut:

$\mathrm{GOIR}_{\mathrm{it}}=\beta_{0}+\beta_{11}\left(\mathrm{ARP}_{\mathrm{it}}\right)+\beta_{2}\left(\mathrm{DR}_{\mathrm{it}}\right)+\beta_{3}\left(\mathrm{FATA}_{\mathrm{it}}\right)$ $+\beta_{4}\left(\operatorname{LOS}_{\mathrm{it}}\right)+\beta_{5}\left(\mathrm{SG}_{\mathrm{it}}\right)+\varepsilon$

Predicted Sign $=\beta_{11}(-) ; \beta_{2}(-) ; \beta_{3}(+/-) ; \beta_{4}(+) ; \beta_{5}$ (+)

Dari hasil regresi, dapat disimpulkan secara simultan bahwa minimal ada satu variabel independen yang mempengaruhi variabel dependennya. Hal ini terlihat dari nilai p-value pada uji $F$ yang signifikan pada $\alpha=0,05$. Nilai adjusted $R^{2}$ sebesar 0.1243 berarti variabel independen dapat menjelaskan variabel dependen GOIR sebesar $12,43 \%$ dan selebihnya dijelaskan oleh variabel lainnya diluar penelitian ini. Dari hasil regresi dengan uji parsial disimpulkan bahwa koefisien dari average receivable period negatif dan signifikan terhadap gross operating income ratio pada $\alpha=0,05$. Hal ini menandakan bahwa kenaikan ataupun penurunan periode pengumpulan piutang dapat mempengaruhi pendapatan operasi dari perusahaan.Nilai koefisien average receivable period sebesar $-0,000308$ berarti penurunan average receivable period sebesar 1 dapat meningkatkan gross operating income ratio sebesar $0,0308 \%$.

Debt ratio digunakan untuk mengukur tingkat utang perusahaan, memiliki pengaruh negatif dan signifikan terhadap variabel dependen. Ini berarti semakin tinggi tingkat utang perusahaan akan mempengaruhi profitabilitas dari perusahaan. Sama halnya dengan LOS yang digunakan untuk mengukur besar perusahaan, menunjukkan pengaruh signifikan positif yang berarti semakin besar perusahaan maka profitabilitasnya lebih besar daripada perusahaan kecil. Fixed financial asset ratio dan sales growth tidak signifikan mempengaruhi profitabilitas perusahaan.

Regresi kedua menggunakan variabel average inventory period (AIP) sebagai variabel independen utama menggantikan average receivable period. Variabel independen lainnya sama dengan regresi pertama. Model yang digunakan adalah sebagai berikut:

$\mathrm{GOIR}_{\mathrm{it}}=\beta_{0}+\beta_{12}\left(\mathrm{AIP}_{\mathrm{it}}\right)+\beta_{2}\left(\mathrm{DR}_{\mathrm{it}}\right)+\beta_{3}\left(\mathrm{FATA}_{\mathrm{it}}\right)$ $+\beta_{4}\left(\operatorname{LOS}_{\mathrm{it}}\right)+\beta_{5}\left(\mathrm{SG}_{\mathrm{it}}\right)+\varepsilon$

Predicted Sign $=\beta_{12}(-) ; \beta_{2}(-) ; \beta_{3}(+/-) ; \beta_{4}(+) ; \beta_{5}$ (+)

Koefisien intersep C memiliki nilai -0,062 dan tidak signifikan. Koefisien dari average inventory period negatif dan signifikan pada $\alpha$ $=0,05$, dan apabila periode persediaan panjang atau pendek akan mempengaruhi profitabilitas. Dengan demikian dapat dikatakan apabila persediaan membutuhkan waktu lebih lama untuk dijual, secara langsung dapat mempengaruhi profitabilitas. Variabel independen debt ratio dan LOS signifikan, sedangkan fixed financial asset ratio dan sales growth tidak signifikan mempengaruhi profitabilitas perusahaan seperti pada regresi pertama. Nilai adjusted $R^{2}$ sebesar 0,1303 berarti variabel independen dapat menjelaskan variabel dependen GOIR sebesar 13,03\% dan selebihnya dijelaskan oleh variabel lainnya diluar penelitian ini. Nilai Prob (F-statistic) sebesar 0,0000 menandakan bahwa model memiliki signifikan yang kuat.

Regresi ketiga menggunakan variabel average payment period (APP) sebagai variabel independen utama menggantikan average inventory period. Variabel independen lainnya 
samaseperti model regresi pertama dan kedua. Model yang digunakan adalah sebagai berikut: $\mathrm{GOIR}_{\mathrm{it}}=\beta_{0}+\beta_{13}\left(\mathrm{APP}_{\mathrm{it}}\right)+\beta_{2}\left(\mathrm{DR}_{\mathrm{it}}\right)+\beta_{3}\left(\mathrm{FATA}_{\mathrm{it}}\right)$ $+\beta_{4}\left(\operatorname{LOS}_{\mathrm{it}}\right)+\beta_{5}\left(\mathrm{SG}_{\mathrm{it}}\right)+$

Predicted Sign $=\beta_{13}(-) ; \beta_{2}(-) ; \beta_{3}(+/-) ; \beta_{4}(+) ; \beta_{5}$ $(+)$

Koefisien intersep $\mathrm{C}$ memiliki nilai -0,131 dan tidak signifikan.Sedangkan koefisien dari average payment period negatif tetapi tidak signifikan.Ini berarti periode pembayaran utang dagang tidak berpengaruh terhadap profitabilitas dari perusahaan. Variabel independen debt ratio dan LOS signifikan, sedangkan fixed financial asset ratio dan sales growth tidak signifikan mempengaruhi profitabilitas perusahaan seperti pada regresi pertama. Nilai adjusted $R^{2}$ sebesar 0,1132 berarti variabel independen dapat menjelaskan variabel dependen GOIR sebesar $11,32 \%$ dan selebihnya dijelaskan oleh variabel lainnya diluar penelitian ini. Nilai Prob ( F-statistic) sebesar 0,0000 menandakan bahwa model memiliki signifikan yang kuat.

Regresi keempat menggunakan variabel cash conversion cycle (CCC) sebagai variabel independen utama menggantikan average payment period. CCC merupakan ukuran komperhensif untuk mengukur manajemen modal kerja.Variabel independen lainnya sama seperti model regresi pertama dan kedua. Model yang digunakan adalah sebagai berikut:

$\mathrm{GOIR}_{\mathrm{it}}=\beta_{0}+\beta_{14}\left(\mathrm{CCC}_{\mathrm{it}}\right)+\beta_{2}\left(\mathrm{DR}_{\mathrm{it}}\right)+\beta_{3}\left(\mathrm{FATA}_{\mathrm{it}}\right)$ $+\beta_{4}\left(\mathrm{LOS}_{\mathrm{it}}\right)+\beta_{5}\left(\mathrm{SG}_{\mathrm{it}}\right)+\varepsilon$

Predicted Sign $=\beta_{14}(-) ; \beta_{2}(-) ; \beta_{3}(+/-) ; \beta_{4}(+) ; \beta_{5}$ $(+)$

Koefisien dari cash conversion cycle negatif dan signifikan pada $\alpha=0,05$. Hal ini berarti panjang atau pendeknya periode konversi kas berpengaruh terhadap profitabilitas dari perusahaan. Variabel independen debt ratio dan LOS signifikan sedangkan fixed financial asset ratio dan sales growth tidak signifikan mempengaruhi profitabilitas perusahaan. Nilai adjusted $R^{2}$ sebesar 0,1344 berarti variabel independen dapat menjelaskan variabel dependen GOIR sebesar 13,44\% dan selebihnya dijelaskan oleh variabel lainnya diluar penelitian ini. Nilai Prob (F-statistic) sebesar 0,0000 menandakan bahwa model memiliki signifikan yang kuat.

\section{Regresi Model: Random Effect - Variabel Dependen Net Operating Income Ratio}

Selanjutnya dilakukan analisis regresi dengan net operating income ratio sebagai variabel dependen. Model yang digunakan untuk melakukan regresi sama seperti pada empat model sebelumnya, yang membedakan hanya variabel dependennya, yaitu net operating income ratio.

Regresi kelima menggunakan variabelnet operating income ratio sebagai variabel dependen dan variabelaverage receivable period (ARP) sebagai variabel independen utama. Variabel kontrol sama seperti pada model sebelumnya. model regresinya sebagai berikut:

$\mathrm{NOIR}_{\mathrm{it}}=\beta_{0}+\beta_{15}\left(\mathrm{ARP}_{\mathrm{it}}\right)+\beta_{2}\left(\mathrm{DR}_{\mathrm{it}}\right)+\beta_{3}\left(\mathrm{FATA}_{\mathrm{it}}\right)$ $+\beta_{4}\left(\mathrm{LOS}_{\mathrm{it}}\right)+\beta_{5}\left(\mathrm{SG}_{\mathrm{it}}\right)+\varepsilon$.

Predicted Sign $=\beta_{15}(-) ; \beta_{2}(-) ; \beta_{3}(+/-) ; \beta_{4}(+) ; \beta_{5}$ (+)

Dari hasil regresi, koefisien dari average receivable period negatif dan signifikan pada $\alpha$ 0,05 . Dapat disimpulkan bahwa panjang pendek nya periode piutang mempengaruhi profitabilitas operasi perusahaan. Variabel independen debt ratio dan LOS signifikan pada $\alpha 0,05$, sedangkan fixed financial asset ratio dan sales growth tidak signifikan mempengaruhi profitabilitas operasi perusahaan. Nilai adjusted $R^{2}$ sebesar 0,1293 berarti variabel independen dapat menjelaskan variabel dependen NOIR sebesar 12,93\% dan selebihnya dijelaskan oleh variabel lainnya diluar penelitian ini. Nilai Prob (F-statistic) sebesar 0,0000 menandakan bahwa model memiliki signifikan yang kuat.

Regresi keenam menggunakan menggunakan variabel net operating income ratio 
sebagai variabel dependen dan variabelaverage inventory period (AIP) sebagai variabel independen utama menggantikan average receivable period. Variabel kontrol yang digunakan sama seperti model sebelumnya. model regresinya sebagai berikut:

$\mathrm{NOIR}_{\mathrm{it}}=\beta_{0}+\beta_{16}\left(\mathrm{AIP}_{\mathrm{it}}\right)+\beta_{2}\left(\mathrm{DR}_{\mathrm{it}}\right)+\beta_{3}\left(\mathrm{FATA}_{\mathrm{it}}\right)$ $+\beta_{4}\left(\operatorname{LOS}_{\mathrm{it}}\right)+\beta_{5}\left(\mathrm{SG}_{\mathrm{it}}\right)+\varepsilon$

Predicted Sign $=\beta_{16}(-) ; \beta_{2}(-) ; \beta_{3}(+/-) ; \beta_{4}(+) ; \beta_{5}$ (+)

Koefisien dari average inventory period negatif dan signifikan pada $\alpha=0,05$, dan apabila periode persediaan panjang atau pendek akan mempengaruhi profitabilitas. Dengan demikian dapat dikatakan apabila persediaan membutuhkan waktu lebih lama untuk dijual, secara langsung akan mempengaruhi profitabilitas. Variabel independen debt ratio dan LOS signifikan, sedangkan fixed financial asset ratio dan sales growth tidak signifikan mempengaruhi profitabilitas perusahaan seperti pada regresi pertama. Nilai adjusted $R^{2}$ sebesar 0,1427 berarti variabel independen dapat menjelaskan variabel dependen NOIR sebesar 14,27\% dan selebihnya dijelaskan oleh variabel lainnya diluar penelitian ini. Nilai Prob (F-statistic) sebesar 0,0000 menandakan bahwa model memiliki signifikan yang kuat.

Regresi ketujuh menggunakan menggunakan variabel net operating income ratio sebagai variabel dependen dan variabel average payment period (APP) sebagai variabel independen utama menggantikan average inventory period.Variabel independen lainnya sama seperti model sebelumnya. Model yang digunakan adalah sebagai berikut:

$\operatorname{NOIR}_{\text {it }}=\beta_{0}+\beta_{17}\left(\mathrm{APP}_{\mathrm{it}}\right)+\beta_{2}\left(\mathrm{DR}_{\mathrm{it}}\right)+\beta_{3}\left(\mathrm{FATA}_{\mathrm{it}}\right)$

$+\beta_{4}\left(\operatorname{LOS}_{\mathrm{it}}\right)+\beta_{5}\left(\mathrm{SG}_{\mathrm{it}}\right)+\varepsilon$

Predicted Sign $=\beta_{17}(-) ; \beta_{2}(-) ; \beta_{3}(+/-) ; \beta_{4}(+) ; \beta_{5}$ (+)

Koefisien intersep $\mathrm{C}$ memiliki nilai $-0,233$ dan signifikan.Sedangkan koefisien dari average payment period negatif tetapi tidak signifikan.Ini berarti periode pembayaran utang dagang tidak berpengaruh terhadap profitabilitas dari perusahaan. Variabel independen debt ratio dan LOS signifikan, sedangkan fixed financial asset ratio dan sales growth tidak signifikan mempengaruhi profitabilitas perusahaan seperti pada regresi pertama. Nilai adjusted $R^{2}$ sebesar 0,1222 berarti variabel independen dapat menjelaskan variabel dependen NOIR sebesar $12,22 \%$ dan selebihnya dijelaskan oleh variabel lainnya diluar penelitian ini. Nilai Prob (F-statistic) sebesar 0,0000 menandakan bahwa model memiliki signifikan yang kuat.

Regresi kedelapan menggunakan menggunakan variabel net operating income ratio sebagai variabel dependen dan variabel cash conversion cycle (CCC) sebagai variabel independen utama menggantikan average payment period. CCC merupakan ukuran komperhensif untuk mengukur manajemen modal kerja.Variabel independen lainnya sama seperti model sebelumnya. Model yang digunakan adalah sebagai berikut:

$\mathrm{NOIR}_{\mathrm{it}}=\beta_{0}+\beta_{18}\left(\mathrm{CCC}_{\mathrm{it}}\right)+\beta_{2}\left(\mathrm{DR}_{\mathrm{it}}\right)+\beta_{3}\left(\mathrm{FATA}_{\mathrm{it}}\right)$ $+\beta_{4}\left(\mathrm{LOS}_{\mathrm{it}}\right)+\beta_{5}\left(\mathrm{SG}_{\mathrm{it}}\right)+\varepsilon \ldots \ldots \ldots \ldots \ldots \ldots \ldots \ldots \ldots \ldots . .(4.8)$

Predicted Sign $=\beta_{18}(-) ; \beta_{2}(-) ; \beta_{3}(+/-) ; \beta_{4}(+) ; \beta_{5}$ $(+)$

Koefisien dari cash conversion cycle negatif dan signifikan pada $\alpha 0,05$. Hal ini berarti panjang atau pendeknya periode konversi kas berpengaruh terhadap profitabilitas dari perusahaan. Variabel independen debt ratio dan LOS signifikan sedangkan fixed financial asset ratio dan sales growth tidak signifikan mempengaruhi profitabilitas perusahaan. Nilai adjusted $R^{2}$ sebesar 0,1527 berarti variabel independen dapat menjelaskan variabel dependen NOIR sebesar $15,27 \%$ dan selebihnya dijelaskan oleh variabel lainnya diluar penelitian ini. Nilai Prob (F-statistic) sebesar 0,0000 menandakan bahwa model memiliki signifikan yang kuat. 
Secara umum, hasil regresi dengan menggunakan variabel dependen gross operating income ratio maupun net operating income ratio mengindikasikan simpulan yang sama yaitu manajemen modal kerja mempengaruhi profitabilitas perusahaan. Jika perusahaan mampu mengelola modal kerja secara efektif maka profitabilitas perusahaan dapat meningkat. Perusahaan juga harus mempertimbangkan penggunaan utang karena mempengaruhi profitabilitas dari perusahaan. Jika perusahaan menaikkan penggunaan utang maka profitabilitas perusahaan akan turun akibat biaya keuangan (cost of financing) yang ditanggung perusahaan. Ukuran perusahaan memiliki pengaruh positif terhadap profitabilitas, semakin besar perusahaan (diukur dari log total penjualan) maka profitabilitas perusahaan juga akan semakin besar. Aset finansial dan pertumbuhan penjualan tidak berpengaruh terhadap profitabilitas dari perusahaan.

\section{KESIMPULAN DAN SARAN}

\section{Kesimpulan}

Banyak perusahaan di Indonesia menginvestasikan kas terlalu banyak pada modal kerja.Hal ini dapat menjadi salah satu jalan bagi perusahaan untuk meningkatkan profitabilitas operasinya dengan mengelolah modal kerja secara efisien. Hasil penelitian ini membuktikan bahwa periode piutang, periode persediaan, dan siklus konversi kas memiliki pengaruh negatif dan signifikan terhadap profitabilitas operasi baik gross operating income ratio maupun net operating income ratio untuk sampel perusahaan manufaktur yang terdaftar di Bursa Efek Indonesia. Hasil tersebut mengindikasikan bahwa manajer dapat meningkatkan profitabilitas operasi perusahaan dengan memperpendek periode piutang dan periode persediaan sampai dengan batas minimum dan rasional bagi perusahaan.

Berdasarkan hasil regresi yang dilakukan, disimpulkan bahwa $\mathrm{H}_{1}$ yang menyatakan bahwa manajemen modal kerja berpengaruh terhadap profitabilitas diterima. $\mathrm{H}_{2}$ yang menyatakan bahwa penggunaan utang berpengaruh terhadap profitabilitasjugaditerima. Dapat dikatakanbahwa semakin besar penggunaan utang perusahaan akan menurunkan profitabilitas perusahaan. Hal ini dikarenakan perusahaan harus menanggung beban keuangan (cost of financing) dari utang tersebut. $\mathrm{H}_{3}$ mengenai ukuran perusahaan dan profitabilitas juga diterima, semakin besar ukuran perusahaan (diukur dari log total penjualan) maka profitabilitas perusahaan juga akan semakin besar. $\mathrm{H}_{4}$ mengenai pertumbuhan penjualan dengan profitabilitas ditolak karena pertumbuhan penjualan tidak berpengaruh dengan profitabilitas perusahaan.

Kesimpulan yang didapat dari penelitian ini sesuai dengan penelitian yang dilakukan Deloof (2003), Raheman (2007), dan Napompech (2012) yang menyatakan bahwa terdapat pengaruh negatif dan signifikan antara manajemen modal kerja dan profitabilitas.

Berdasarkan analisis diatas, peneliti menyimpulkan bahwa hasil tersebut dapat diperkuat jika perusahaan mengelolah modal kerja mereka dengan lebih efisien.Mengelolah modal kerja berarti mengelola aset lancar dan kewajiban lancar serta pembiayaan atas aset lancar tersebut. Jika perusahaan dapat mengelolah kas, piutang, dan persediaan dengan cara yang tepat, pada akhirnya profitabilitas perusahaan akan meningkat.

\section{Saran}

Dengan melihat simpulan diatas, berikut ini saran yang dapat diberikan peneliti:

1. Bagi perusahaan publik terutama perusahaan manufaktur, jika perusahaan dapat memperpendek periode penagihan piutang dan periode konversi bahan bakumenjadi barang jadi sampai menjualnya ke tingkat minimum dan rasional perusahaan dapat meningkatkan pendapatan atas operasinya. 
2. Bagi investor ataupun calon investor dapat mempertimbangkan melakukan investasi pada perusahaan publik yang mengelola modal kerja dengan cara yang tepat.

3. Bagi akademisi, peneliti dapat menyarankan beberapa hal, yakni sebagai berikut:

a. Variabel dependen lebih diperluas, dalam penelitian ini variabel dependen hanya menggambarkan tingkat profitabilitas operasional dari perusahaan, karena sebenarnya GOIR dan NOIR lebih menggambarkan tingkat profitabilitas terkait dengan kegiatan operasi.

b. Penelitian ini menggunakan rentang waktu lima tahun. Disarankan agar penelitian selanjutnya menggunakan rentang waktu yang lebih panjang agar hasil penelitian dapat lebih menggambarkan fluktuasi dan perubahan kondisi manajemen modal kerja dan variabel-variabel terkait lainnya.

c. Penelitian selanjutnya dapat dilakukan pada sektor berbeda tidak hanya manufaktur dan tidak hanya terbatas pada perusahaan publik.

\section{d. DAFTAR PUSTAKA}

Brigham, Eugene F, \& Houston, Joel F.2001. Manajemen Keuangan, Buku dua. (Penerjemah: Dodo Suharto \& Herman Wibowo). Jakarta: Erlangga.

Brigham, Eugene F., \& Houston, Joel F.2010. Dasar-dasar Manajemen Keuangan, Buku satu (edisi kesebelas). Jakarta: Salemba Empat.

Deloof, Marc.2003. Does working capital management affect probability of Belgian firms?.Journal of Business Finance \& Accounting, 30 (3) \& (4), 573-578.

Gill, Amarjit. Biger, Nahum., \& Mathur, Neil.2010. The relationship between working capital management and profitability: evidance from the United States. Business and Economics Journal, vol 2010: BEJ-10.

Gujarati, Damodar N,.and Porter, Dawn C.2012. Dasar - dasar ekonometrika, buku 2 (edisi kelima). (Penerjemah: Raden Carlos Mangunsong). Jakarta: Salemba Empat.

Gujarati, Damodar N.2003. Basic Econometrics (4th ed). New York: McGraw Hill.

Husnan, Suad.1998. Manajemen Keuangan Teori dan Penerapan (keputusan Jangka Pendek) buku 2. Yogyakarta: BPFEYogyakarta.

Karnadi, Steve H.1993. Manajemen Pembelanjaan jilid 1. Jakarta: Promotio Hutama.

Kautsari, R.rr Ken Berlian.2012. Pengaruh Manajemen Modal Kerja Terhadap Profitabilitas Perusahaan pada Perusahaan Rokok yang Terdaftar di Bursa Efek Indonesia.Fakultas Ekonomi Universitas Brawijaya.

Martin, Jhon D., Petty, J. William., Keown, Arthur J., Scott, David F. 2001.Foundation of Finance: The Logic and Practice of Financial Management (3rd Ed). New Jersey: Prentice Hall.

Nachrowi, Nachrowi Djalal,. Dan Usman, Hardius. 2006. Pendekatan popular dan praktis ekonometrika analisis ekonomi dan keuangan. Jakarta: Lembaga penerbit FE-UI.

Napompech, Kulkanya.2012. Effects of working capital management on the profitability of Thai listed firms. International Journal of Trade, Economics and Finance 3 (03).

Raheman, Abdul,. And Nasr, Mohamed.2007. Working capital management dan profitability - Case of Pakistan firms. International Review of Business Research Papers, 3 (01), 279-300. 
Rasul, Agung Abdul.2011. Ekonometrika formula dan aplikasi dalam manajemen. Jakarta: Mitra Wacana Media.

Riyanto, Bambang.1997. Dasar-dasar Pembelanjaan Perusahaan. Yogyakarta: Yayasan Badan Penerbit Gadjah Mada.

Ross, Stephen A., Westerfield, Randolph W., \& Jordan, Bradford D.2008.Corporate Finance Fundamentals.Boston: Irwin/ McGraw-Hill.
Weston, J.Fred.,\& Copeland, Thomas E.1999. Manajemen Keuangan (edisi kedelapan). (Penerjemah: Jaka Wasana \& Kirbrandoko). Jakarta: Penerbit Erlangga. (Buku asli diterbitkan 1989).

Widarjono, A.2007. Ekonometrika: Teori dan Aplikasi untuk Ekonomi dan Bisnis. Edisi Kedua. Yogyakarta: Ekonisia Fakultas Ekonomi Universitas Islam Indonesia. 